Danko Zelić

Institut za povijest umjetnosti, Zagreb

\title{
Projekt Fausta Vrančića za opsadu Ostendea iz 1603. godine
}

\author{
Prethodno priopćenje - Preliminary communication \\ Primljeno - Received 19. 9. 2019. \\ UDK 001.894:623.444Vrančić, F."1603" \\ DOI 10.31664/ripu.2019.43.14
}

\begin{abstract}
Sažetak
U radu se predstavlja projekt za zatvaranje morskog pristupa luci Ostendea što ga je Faust Vrančić načinio 1603. godine, u jeku opsade
\end{abstract}

toga grada, i iz Praga poslao zapovjedniku opsadnih trupa nadvojvodi Albrechtu VII.

Ključne riječi: Faust Vrančić, opsada Ostendea, ratne naprave, 17. stoljeće, vojno inženjerstvo, izumiteljstvo, Pompeo Targone

Ujesen 1603. godine Faust Vrančić iz Praga je nadvojvodi Albrechtu VII., vladaru Španjolske Nizozemske i zapovjedniku trupa koje su tijekom proteklih dviju godina bezuspješno opsjedale Ostende, poslao pismo s nacrtom vlastitog izuma za sprečavanje morskog pristupa luci toga grada. Po svemu sudeći, Vrančićev prijedlog nije bio prihvaćen, a dokument je odložen ad acta. Proći će više od tri i pol stoljeća prije no što će ga, u središnjem državnom arhivu Kraljevine Belgije u Bruxellesu, ${ }^{1}$ uočiti mađarski povjesničar Kálmán Benda. Podatak o tome, uz kratak komentar, obznanio je 1973. godine njegov sunarodnjak László Makkai u zborniku radova posvećenom Fernandu Braudelu. ${ }^{2}$ U mađarskoj je historiografiji otad, koliko nam je poznato, o tom projektu bilo riječi još u dva navrata. Godine 1985. u Vrančićevu životopisu, u pogovoru knjige s mađarskim prijevodima njegovih tekstova, spomenula ga je Katalin S. Varga, objavivši pritom i faksimil pisma, ${ }^{3}$ a u zborniku radova o Faustu Vrančiću tiskanom 1994. godine u Veszprému, kratku je crticu na istu temu, s transkripcijom teksta pisma te faksimilom nacrta, publicirao István Monok. ${ }^{4}$

Dokument u briselskom arhivu neprijeporno je dragocjena nadopuna "katalogu" Vrančićevih izuma. U prvom redu izuzmemo li, dakako, naprave riječju i slikom predstavljene u knjizi Machinae novae (1615.) - riječ je o jedinom poznatom slikovnom prikazu nekog njegova izuma. K tomu, posrijedi nije iznašašće "konceptualne" naravi, nego rješenje specifič- nog, stvarnog problema, nastalo, što je ne manje važno, na izumiteljevu vlastitu inicijativu.

Budući da su vijesti o Faustovu projektu za Ostende u hrvatskoj znanstvenoj historiografiji ostale bez odjeka, ${ }^{5}$ svrha je ovog rada ponajprije rasvijetliti povod i okolnosti njegova nastajanja, naznačiti najvažnija svojstva same projektne zamisli te preliminarno uputiti na nekoliko pitanja o kojima bi trebalo povesti računa u istraživanjima koja slijede.

\section{Opsada Ostendea}

Opsada Ostendea središnji je događaj tzv. Osamdesetogodišnjeg rata koji se na prostorima današnjih Kraljevina Belgije i Nizozemske vodio između trupa legitimnih suverena Španjolske Nizozemske, vladara iz (španjolskog ogranka) kuće Habsburg, na jednoj, te vojske Ujedinjenih nizozemskih pokrajina na drugoj strani. Rat koji će biti obilježen prije svega opsadama gradova, započeo je 1568 . godine osnivanjem Saveza nizozemskih pokrajina. Nakon početnih uspjeha pobunjenika, zauzećem Antwerpena 1585. godine u cijeloj je južnoj Nizozemskoj (Flandriji) ponovno uspostavljena habsburška vlast, a jedinom enklavom pod kontrolom Nizozemaca ostao je Ostende, grad na obali Sjevernog mora. Ubrzo u očekivanju opsade ondje započinju opsežni fortifikacijski radovi. Dotad gradić nevelike strate- 


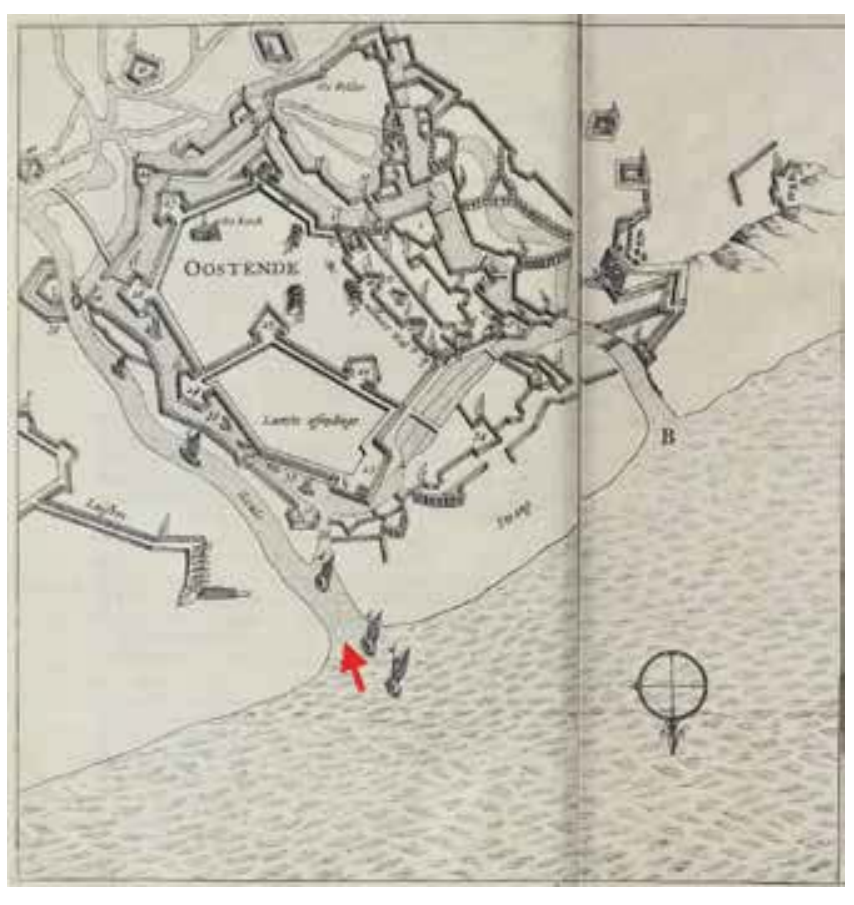

1. Ostende, shematski plan grada pod opsadom, izvor: Matthias Dögen, Architectura militaris moderna (...), Amstelodami, 1647., 354-355; strelicom je označeno ušće kanala De Geule - mjesto uplovljavanja brodova kojima je dopremana pomoć braniteljima

Ostend, perspective drawing of the town under siege; the arrow points to the mouth of the De Geule channel; i.e. the entrance for ships with troops and supplies for the defenders

gijske važnosti, nastao uz ribarsku luku, ${ }^{6}$ Ostende na izmaku 16. stoljeća postaje jednom od najsnažnijih utvrda Europe; grad je pretvoren u otok utvrđen dvama koncentričnim pojasima bedemima ojačanih bastiona između kojih su bili opkopi s vodom. ${ }^{7}$

Opsada Ostendea započela je 5. srpnja 1601. godine. ${ }^{8}$ Okupivši petnaestak tisuća vojnika, najvećim dijelom Španjolaca, nadvojvoda Albrecht VII. (od 1596. namjesnik, a od 1599., zajedno sa suprugom Izabelom, suvladar Španjolske Nizozemske) zarekao se da će osvojiti grad makar mu za to trebalo i osamnaest godina. ${ }^{9}$ Okružen kontinuiranim pojasom novoizgrađenih španjolskih fortifikacija, Ostende je od početka opsade bio posve odsječen od svoga kopnenoga zaleđa. Pomoć u ljudstvu, naoružanju i namirnicama u grad je otada mogla stizati isključivo morem gdje je premoć imalo brodovlje Nizozemaca i njihovih saveznika Engleza. Za prihvat plovila branitelji su osposobili novu luku (Nieuwe Haven), uređenu između dva pojasa bedema na istočnom dijelu oboda fortifikacija; u luku se uplovljavalo ušćem nedugo prije prokopana kanala De Geule (sl. 1). Tijekom opsade koja će potrajati više od tri godine španjolska je vojska ustrajno ali bez uspjeha pokušavala presjeći tu, za obranu Ostendea životno važnu komunikaciju. ${ }^{10}$ Razinu vode u opkopima bilo je moguće kontrolirati sustavom ustava i zapornica kojim se upravljalo iz grada, a u svojim naporima za zatvaranjem pristupa brodovima napadači su, k tomu, nerijetko bivali spriječeni nepovoljnim vremenskim prilikama na tom dijelu sjevernomorskog priobalja. Okončana predajom branitelja

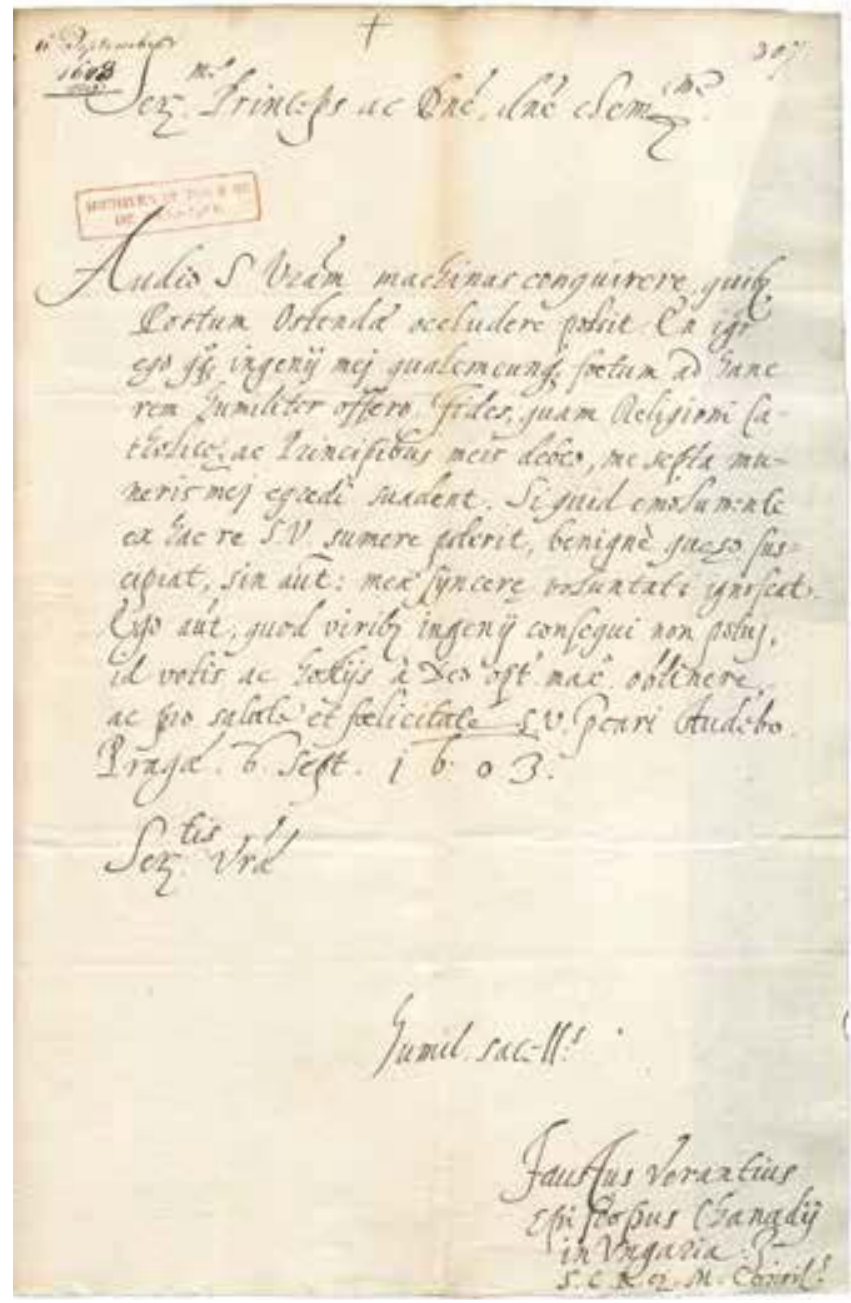

2. Faksimil pisma Fausta Vrančića nadvojvodi Albrechtu VII. (Rijksarchief in België/ Archives de l'État en Belgique, Algemeen Rijksarchief / Archives générales du Royaume, Fond Duitse Staatssecretarie/ Secrétairerie d'État Allemande, 413, p. 307)

Facsimile of Faust Vrančićs letter to archduke Albert VII

20. rujna 1604., opsada Ostendea ostat će daleko najkrvavijom epizodom Osamdesetogodišnjeg rata. Procjene broja ubijenih i ranjenih vojnika na objema stranama kreću se čak do stotinjak tisuća, a grad koji je gotovo posve razoren nazvan je Novom Trojom. ${ }^{11}$

\section{Pismo nadvojvodi Albrechtu VII.}

U trenutku u kojem Faust Vrančić šalje svoj projekt - 6. rujna 1603. godine - opsada Ostendea ušla je u treću godinu, a položaji suprotstavljenih strana na ratištu uglavnom su ostali nepromijenjeni. U vlastitom rukom napisanom, kratkom i formalno sročenom popratnom pismu na latinskom (sl. 2; Prilog 1), što će ga potpisati kao "ponizni svećenik, Biskup Čanada u Ugarskoj i Carski vijećnik «, Vrančić se naslovniku, nadvojvodi Albrechtu VII., obraća izravno. Budući da je »čuo« da njegova »Prejasnost traži načine za zatvaranje luke Ostendea«, smjerno mu nudi »porod vlastita uma«, ističući 


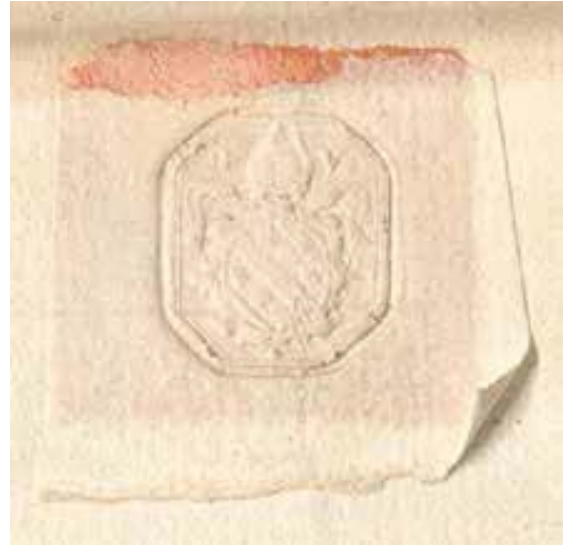

3. Biskupski pečat Fausta Vrančića na naličju lista - omotu pisma (Rijksarchief in België/ Archives de l'État en Belgique, Algemeen Rijksarchief/ Archives générales du Royaume, Fond Duitse Staatssecretarie/ Secrétairerie d'État Allemande, 413, p. 308)

The episcopal seal of Faust Vrancicic on the reverse side of the leaf, i.e. the outer envelope of the letter

da su ga na taj iskorak izvan "granica svojih službi« potaknule upravo »odanosti prema katoličkoj vjeri i prema svojim [habsburškim] vladarima«. U nadi da će od njegova izuma biti neke koristi, ponizno moli nadvojvodu da ga prihvati, a u protivnom neka mu ne zamjeri jer su mu pobude bile iskrene. U posljednjoj rečenici uvjerava ga da će »ono što nije postigao snagom svog uma «, nastojati ishoditi »zavjetima i žrtvama« Bogu, moleći se za zdravlje i sreću nadvojvode.

$\mathrm{Na}$ naličju lista - omotnici - Vrančić je napisao adresu s punom titulom primatelja te pismo zapečatio svojim biskupskim pečatom (sl. 3). ${ }^{12}$ Grb unutar pečata, s dvjema kosim gredama i »ljiljana šest «, biskupskom mitrom te inicijalima $\mathrm{F}$ i V, ${ }^{13}$ identičan je grbu nad atikom fontane na jednom od crteža u knjizi Machinae novae. ${ }^{14}$ Pokraj pečata Vrančić je kurzivnim rukopisom u tri retka dodao: Faustus Verantius Episcopus Chanadiensis de portu Ostendano obstruando.

\section{Projekt}

U pismu se projektna zamisao ne pojašnjava; Vrančić je zacijelo vjerovao da je priloženi nacrt (sl. 4) - akvarelirani crtež tušem, na papiru većih dimenzija $(63 \times 43,9 \mathrm{~cm})^{15}$ - sam po sebi dostatno rječit. Prikazan shematski, u okomitoj projekciji (tj. u tlocrtu), izum se sastojao od dviju vrsta zapreka raspoređenih cijelom širinom plovnog puta. U gornjem su dijelu crteža dva niza (od šest odnosno pet) paralelnih, naizmjence uzdužno postavljenih masivnih drvenih greda. Krajevi su im usađeni u dno, a zašiljeni i željezom okovani vrhovi lancima vezani za sidra. U donjem dijelu crteža tri su reda zapreka koje se sastoje od kraćih, poprečno postavljenih i lancima međusobno spojenih drvenih greda, također lancima vezanih uz sidra. Vodotok je obojen svjetlijom plavom, grede svjetlosmeđom, a metalni dijelovi (lanci, okovi i sidra) tamnijom nijansom plave boje.

Premda načinjen za opsadnu vojsku, Vrančićev se projekt može svrstati u defenzivne ratne naprave. Uzdužno po- stavljenim zašiljenim gredama svrha je bila oštećivanje i/ili probijanje pramčanih dijelova brodskog trupa, a poprečno postavljenim gredama da konačno zaustave plovila. O tome na koji je način (i koliko duboko) izumitelj predvidio da uzdužno postavljene grede budu fiksirane u dno i je li zamislio da šiljci okrenuti k brodovima koji su uplovljavali u luku budu na površini vode ili ispod nje, može se samo nagađati.

Možda u svezi s potonjim, na crtežu je jasno razvidna i evolucija projektne zamisli, točnije dvije faze "razrade" projekta. One se očituju u pojašnjenjima u dopisanim "legendama” (Prilog 2) te u prepravljenim ili docrtanim pojedinostima. Na nekoliko uzdužno postavljenih greda (u gornjem dijelu crteža) Vrančić je napisao trabes, a na desnoj margini lista upozorio je da sidreni lanci trebaju biti dugi (tj. dulji) te da sidra trebaju biti četverokraka (a ne, kao na crtežu, dvokraka), uz napomenu da je "slikar pogriješio«. Očito je da je naknadno i precrtao ušice dvokrakih sidara. Još je važnija izumiteljeva intervencija u donjem dijelu crteža; između nizova poprečnih plutajućih greda dopisao je da lanci trebaju biti ispruženi a ne - kao što je to nacrtano - ovijeni oko greda; upravo onako kako je to ilustrirao na slobodnim prostorima lijevo i desno, docrtavši sa svake strane još po jednu gredu s duljim, ispruženim lancem i četverokrakim sidrom. Napomena o sidrima imala je, dakle, vrijediti ne samo za sidra u gornjem nego i za ona u donjem dijelu crteža.

Vrančić je, razumije se, jamačno najprije načinio skicu koju je dao precrtati u čisto nepoznatom suradniku kojeg naziva slikarom, da bi potom vlastitom rukom korigirao njegov rad. Preinake u projektu možda su rezultat naknadno stečenih podrobnijih informacija o prilikama na samoj lokaciji, $u$ prvom redu, kako se čini, o tamošnjim osjetnim mijenama morske razine; tražena veća fleksibilnost ( $t j$. raspon vertikalnog kretanja vrhova greda) trebala je biti omogućena produljivanjem lanaca. Na belgijskom dijelu obale Sjevernog mora razlika u razini mora tijekom plima i oseka što se izmjenjuju u redovitim poludnevnim ciklusima danas uglavnom varira između 4 i 5 metara (najveća zabilježena razlika vodostaja u Ostendeu iznosi 5,89 m). ${ }^{16}$ Ako doista nije riječ o pogrešci »slikara«, pretpostavka o naknadno prikupljenim informacijama mogla bi vrijediti i za modifikaciju oblika sidara; na pjeskovitim morskim dnima, poput onih na obali kod Ostendea, četverokraka su sidra nedvojbeno prikladnija od dvokrakih.

S obzirom na učinkovitost naprave, moguće je primijetiti kako je najproblematičnija strana projektne zamisli bila $\mathrm{u}$ tome što su zašiljeni vrhovi uzdužno postavljenih greda mogli skliznuti uz pramce plovila, tj. da ni na koji način nije bilo osigurano da ih brodovi pramcima ne razmaknu. Sidreni lanci kojima su vrhovi greda bili pričvršćeni uz dno omogućavali su, naime, neometano dizanje i spuštanje šiljaka, ali projektom nije spriječeno njihovo eventualno pomicanje po horizontalnoj osi. K tomu, kretanje vrhova greda po vertikalnoj osi (zbog povećavanja ili smanjivanja vodostaja) vjerojatno bi postupno dovelo do ispadanja u dno usađenih krajeva greda iz njihovih ležišta. Kada je pak riječ o drugom segmentu zapreke, rješenje s poprečno postavljenim gredama povezanim lancima po svemu je sudeći nadahnuto plutajućim lancima (catena portus) koji su od pamtivijeka 


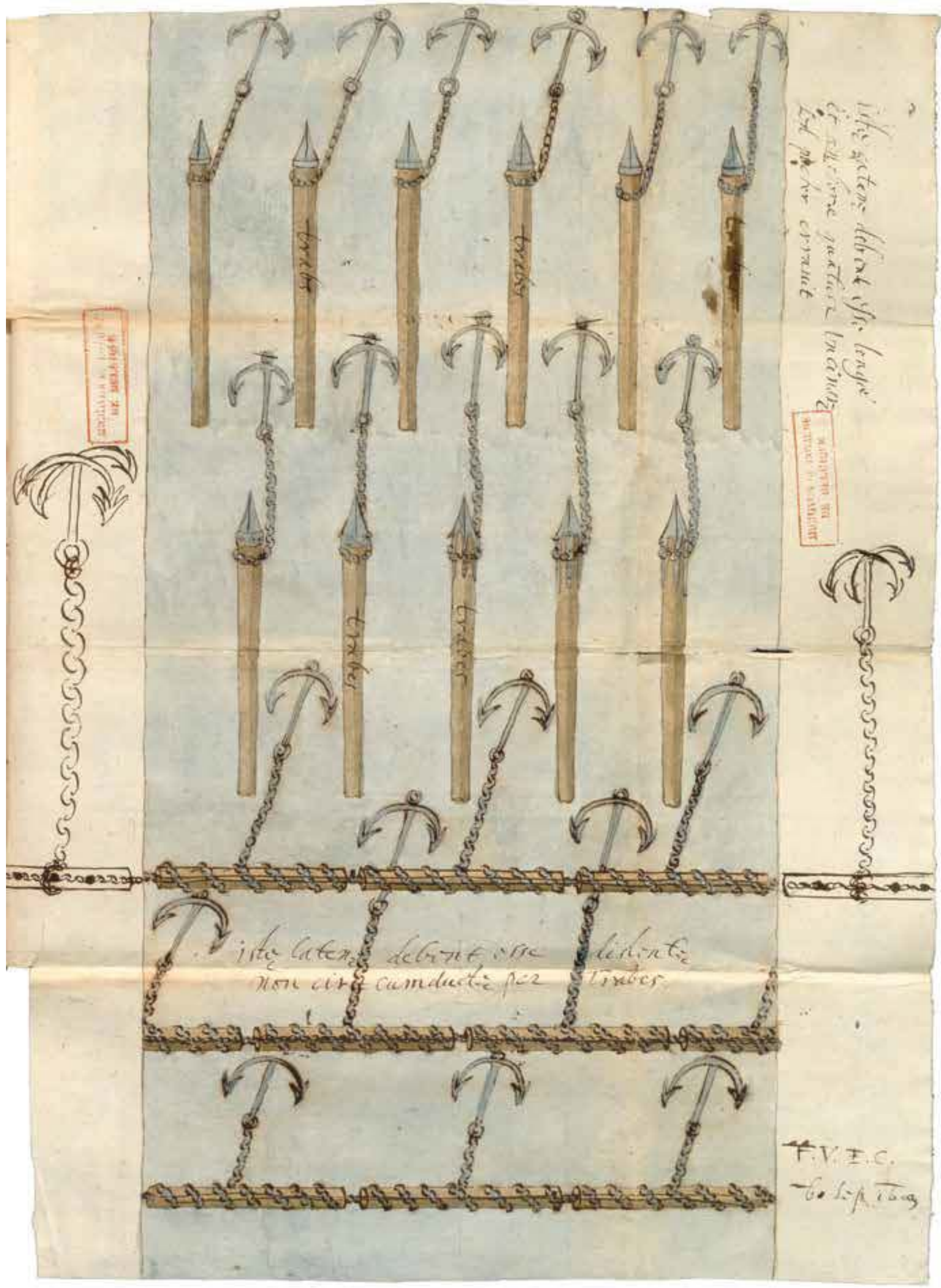


posvuda na Mediteranu, pa tako, primjerice, i u Vrančićevu rodnu Šibeniku, ${ }^{17}$ postavljani na ulazima u luke radi nadzora u ratnim, ali i mirnodopskim uvjetima.

\section{Faust Vrančić i Pompeo Targone}

Za raspravu o meritumu vrijednosti Vrančićeva - premda, kao što je već istaknuto, najvjerojatnije nerealizirana - izuma, njegov je projekt nužno sagledati unutar općenitih okvira izumiteljstva tog doba, ali prije svega u kontekstu ratovanja oko Ostendea.

Tijekom iscrpljujuće trogodišnje opsade u kojoj su Španjolci »osvajali neosvojivo«, a Nizozemci »branili neobranjivo «, ${ }^{18} \mathrm{u}$ Ostende su bile uprte oči cijele Europe. Osim vojne dimenzije - očite već u dotad neviđenoj množini angažiranih trupa i gubitcima u ljudstvu na objema stranama - opsada Ostendea bila je događaj bremenit političkim, ali i simboličkim konotacijama. Posrijedi nije bilo samo, s jedne strane borba za neovisnost, a s druge gušenje pobune protiv zakonitog vladara, nego sukob koji je imao, ništa manje važno, međukonfesionalno obilježje. Vijesti o zbivanjima oko Ostendea jamačno nije manjkalo niti na dvoru cara Rudolfa II. u Pragu, tadašnjoj prijestolnici Carstva, gdje će se Faust Vrančić u službi vladara zadržati sve do početka 1605. godine.

Ratovanje oko Ostendea na objema je stranama privuklo brojne profesionalce - vojnike, časnike, vojne inženjere, liječnike - željne neposrednog ratnog iskustva, zarade, ili slave. U godinama opsade Ostende je stoga prozvan Ratnim sveučilištem (Kriegs-Universiteit), ${ }^{19}$ a ondje su, dakako, među inim, s većim ili manjim uspjesima projektirane i iskušavane brojne inovativne vojne naprave. ${ }^{20}$

U tom su pogledu, ako ne zbog drugoga, onda svakako zbog odjeka koji su imali u povijesnim kronikama toga doba, nedvojbeno najglasovitiji ratni strojevi svestranoga rimskog inženjera Pompea Targonea (Rim, 1575. - Milano, 1630.). ${ }^{21}$ Targone je u Ostende stigao 1602. ili 1603. godine, ${ }^{22}$ a prethodno je radio u službi pape Klementa VIII., istakavši se u umijeću lijevanja i obrade metala. ${ }^{23}$ Čini se da je svoja prva vojnoinženjerska iskustva stjecao još u osamdesetim godinama 16. stoljeća, i to upravo na flamanskim ratištima, ${ }^{24}$ te da je iz Rima poslan u pomoć vojsci katoličkog vladara prije svega sa zadaćom pronalaženja rješenja za sprečavanje uplovljavanja neprijateljskih brodova u luku Ostendea. Opsadne naprave koje je ondje projektirao i izveo poznate su zahvaljujući opisima i grafičkim prikazima u knjižnim edicijama. ${ }^{25}$ Stjecajem okolnosti, Targone će - bar kada je posrijedi taj dio njegove karijere - ostati zapamćen kao poslovičan primjer vojnog inženjera "za crtaćom daskom".

Uistinu, iz današnje se perspektive čini gotovo nevjerojatnim da su neke od Targoneovih zamisli - poput divovskog

4. Crtež izuma Fausta Vrančića - naprave za zatvaranje pristupa luci Ostendea (Rijksarchief in België/Archives de l'État en Belgique, Algemeen Rijksarchief/ Archives générales du Royaume, Fond Duitse Staatssecretarie / Secrétairerie d'Etat Allemande, 413, p. 309)

The drawing of Faust Vrančićs invention to obstruct maritime access to the port of Ostend

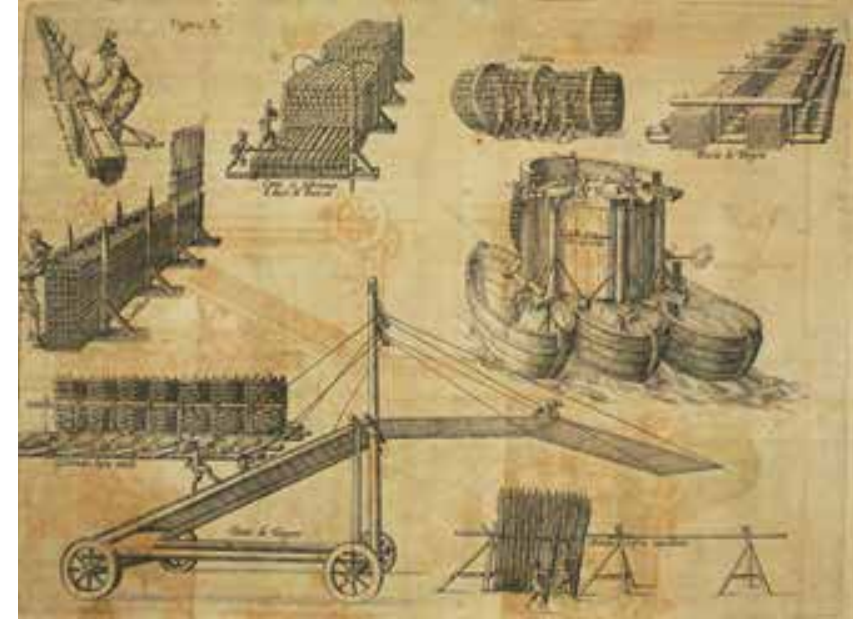

5. Vojne naprave na ratištu kod Ostendea, izvor: Pompeo Giustiniano, Delle guerre di Fiandra libri 6. Di Pompeo Giustiniano del Consiglio di guerra di S. M. C. ... Posti in luce da Gioseppe Gamurini ... con le figure delle cose più notabili, In Anversa, 1609., Figura X, izm. str. 84 i 85 (gore desno - Troccio di Targone; sredina desno - Castello di Targone che non servi; dolje lijevo - Ponte di Targone)

War machines employed during the siege of Ostend (top right - Troccio di Targone; middle right - Castello di Targone che non servi; bottom left - Ponte di Targone)

pokretnog mosta za prelazak vojnika preko zidina ("Pompejeva kočija") ili, pak, plutajuće tvrđave usidrene nasuprot ušću kanala De Geule (“Targoneov kaštel”) - uopće bile razmatrane, a kamoli izvedene. Onesposobljene a potom i uništene preciznim topničkim hitcima branitelja, dvije se navedene naprave doimaju jednako toliko problematičnima koliko su spektakularni bili njihovi neuspjesi. Ipak, Targone je za opsadu Ostendea osmislio i druge, nedvojbeno učinkovitije vojne naprave kojima su također bivala nadijevana slikovita imena; njegov je izum za koordiniranje paljbe iz više artiljerijskih oruđa na talijanskom nazvan civetta (sova), ${ }^{26}$ pokretni zakloni za pješaštvo prozvani su salsiccia (kobasica) ili salsiccione (kobasičetina), a dvostrani plutajući zaklon od drvenih greda na bačvama troccio (koš), itd. ${ }^{27}$

Neuspjesi Targoneovih naprava na ratištu kod Ostendea, unatoč porugama s kojima su ih dočekali branitelji, nisu ozbiljnije narušili ugled toga svestranog inženjera u Rimu. Vrativši se ondje na poziv pape Pavla V. nedugo poslije okončanja borbi pod Ostendeom, godine 1605. imenovan je glavnim papinskim inženjerom za vodotoke (sopra le acque), ${ }^{28} \mathrm{a}$ potom i generalom topništva te glavnim inspektorom svih utvrda papinske države. ${ }^{29}$ Od 1607 . ponovno je u svojstvu vojnog inženjera u Flandriji kamo ga je papa uputio na molbu zapovjednika španjolske Flamanske armade Ambrogia Spinole, istoga onog vojskovođe koji je - preuzevši zapovijedanje opsadom ujesen 1603. godine - tri godine ranije izvojevao predaju Ostendea. K tomu, još u poznoj životnoj dobi Targone će se kao inženjer u službi francuskog kralja Luja XIII. istaknuti u opsadi i zauzeću grada La Rochellea. ${ }^{30}$

U svjetlu navedenih činjenica nameće se zaključak da je za loš glas koji je Targonea kao vojnog inženjera pratio u Flandriji zaslužna ponajprije nizozemska propaganda, širena $u$ mnogim, u ono doba vrlo popularnim knjižnim edicijama 
o opsadi Ostendea. ${ }^{31} \mathrm{~K}$ tomu, iskusnim profesionalnim časnicima koji su u tim zbivanjima izravno sudjelovali, pa i onima koji su se, poput Pompea Giustinianija, borili na strani napadača, namjera je pak bila upozoriti na štete koje su proizlazile iz raskoraka između "teorije i prakse". ${ }^{32}$ Prikazan kao izumitelj vojnih sprava bez neposrednoga ratnog iskustva, Targone im je u tome poslužio kao idealan primjer. Činjenica da su se obojica, svatko na svoj način, bili pozabavili iznalaženjem inženjerskih rješenja za glavni vojni problem u opsadi Ostendea nije, međutim, jedina poveznica između Fausta Vrančića i Pompea Targonea.

U komentarima svojih naprava u knjizi Machinae novae, Faust Vrančić na više mjesta spominje izumiteljstvo i izume svojih suvremenika; jedini od njih kojeg je naveo imenom bio je upravo Targone. ${ }^{33}$ I ta činjenica - koja, usput rečeno, u historiografiji nije uočena - svjedoči kako je Targoneov prestiž u Rimu u vremenu u kojem ondje boravi i Faust Vrančić (između 1605. i 1614. godine) bio neupitan.

Kao glavnom papinskom inženjeru za vodotoke, Targoneova je najvažnija zadaća bila regulacija rijeke Tiber. ${ }^{34}$ Nezapamćena izlijevanja Tibera zabilježena su 1589. i 1598. godine, a doputovavši u Rim 1605., ${ }^{35}$ Faust Vrančić neprijeporno je i sam izravno doživio katastrofalnu poplavu na prijelazu iz te u 1606. godinu. Na problemu plavljenja Tibera okušavali su se mnogi rimski inženjeri toga doba, ${ }^{36}$ a vlastito je hidrotehničko rješenje - i to projektom što će ga u knjizi Machinae novae odlučiti uvrstiti na prvo mjesto - ponudio i Faust Vrančić. ${ }^{37}$

Povrh naprava predstavljenih grafikama i opisnim tekstovima, na kraju tekstualnih dijelova svoje petojezične "knjige strojeva” Faust Vrančić dao je tiskati popise još šezdesetak svojih izuma. ${ }^{38}$ Među njima nalazimo i "Lanac kojim se zatvaraju rijeke i morske luke« (na latinskom: Catena qva Flumina et Portus Maris occludantur), ${ }^{39}$ što, dakako, priziva u sjećanje njegov projekt za Ostende. No usporedba vijesti o Targoneovim rimskim izumima sačuvanih u dokumentarnim izvorima s nazivima Faustovih naprava u spomenutom popisu upućuje na još jednu podudarnost vrijednu pozornosti. Vrančićev izum plutajućih »nepokretnih mlinova koji za dizanja i spuštanja vodostaja rijeka ne skreću pravac njihovih tokova" (Moloe stabiles, qvoe fluminibus crescentibus, et de- crescentibus, à suo cursu non impediuntur) asocira, naime, na mlinove uz pokretni drveni most što će ih Targone, ishodivši prethodno za to papinsku koncesiju, izgraditi na Tiberu 1617., dvije godine poslije tiskanja Vrančićeve knjige. ${ }^{40}$

Dakako, podatci kojima raspolažemo nedostatni su za iole ozbiljniju raspravu o eventualnim sličnostima navedenih izuma, sklonosti "posuđivanju” ili čak preuzimanju tuđih rješenja. Usprkos autoritetu visokog papinskog službenika, od takvih optužbi svojih suparnika, rimskih »arhitekata «, neće ostati pošteđen ni Targone. ${ }^{41} \mathrm{Ni}$ njegov most s mlinovima na Tiberu nije bio dugoga vijeka; za iznenadna visokog vodostaja otplavila ga je bujica. ${ }^{42}$ Neuspjesi, neshvaćenost, omalovažavanje i pokušaji osporavanja bili su i ostali sastavnim dijelom životnog iskustva zacijelo svakog izumitelja. Vrančić će o tome u završnom dijelu proslova svoje knjige zapisati:

(...) Ipak znam da su ljudi takvi da će mnogi od njih, pošto su vidjeli ove moje strojeve ili izrađene instrumente, pa i prije nego što su ih vidjeli, već samo pročitali o njima u katalogu i visoko ih ocijenili, prezirati ih i smatrati ih običnim stvarima. Zašto sam onda potrošio toliko truda i rada da ih opišem? Upravo zato da udovoljim sebi, a također i onim malobrojnima, koji će do toga nešto držati. Molim da bi drugi, onako kako će to moći, dali na svjetlo dana bolje ili dalje pronalazili, kako bi se ove strojeve moglo napustiti, a druge primjenjivati. (... $)^{43}$

Zbog svega toga, premda se čitatelju mogu učiniti kao bespotrebne digresije, smisao poduljih navoda o životu i djelima izumitelja i Vrančićeva suvremenika Pompea Targonea u ovom radu jest upravo u podsjećanju na činjenicu da u istraživanjima izumiteljstva i izuma početkom 17. stoljeća podatke u todobnim narativnim i dokumentarnim izvorima treba sagledavati unutar totaliteta povijesne stvarnosti ranog novovjekovlja. To prije svega treba imati na umu kada se pokušavaju postavljati pitanja o mjeri »izvornosti « $\mathrm{i}$ »autorstva « pojedinih izuma u vremenima koja su - poglavito kada su posrijedi tehnika i tehnologija - bila obilježena iskustvenošću, tj. empirijskim a ne znanstvenim (u današnjem smislu riječi) karakterom spoznaja. Današnja poimanja izvornosti i autorstva tehnoloških izuma, zasnovana na postulatima provjerljivosti i dokazljivosti, proizlaze iz svijesti koja će se javiti tek u razdoblju prosvjetiteljstva razvojem egzaktnih disciplina, ponajprije matematike i fizike. ${ }^{4}$ 
Prilozi

\section{Pismo Fausta Vrančića nadvojvodi Albrechtu VII. - Prag, 6. rujna 1603.}

\section{$\dagger$}

Serenissime Princeps ac Domine, domine Clementissime,

Audio Serenitatem Vestram machinas conquirere, quibus Portum Ostendoe occludere possint. En igitur ego quoque ingenii mei qualemcunque fotum ad hanc rem humiliter offero. Fides, quam Religioni Catholice, ac Principibus meis debeo, me septa muneris mei egredi suadent. Si quid emolumenti ex hac re Serenitas Vestra sumere poterit, benignè quęso suscipiat, sin autem, mex siincere voluntati ingnoscat. Ego autem, quod viribus ingenii consequi non potui, id votis ac hostiis à Deo Optimo Maximo obtinere, ac pro salute et foelicitate Serenitatis Vestroe procari studebo.

Prage, 6. Septembris 1603.

Serenitatis Vestrce

humilis sacellanus

Faustus Verantius

Episcopus Chanadii

in Ungaria

$S[$ acræe]. $C$ [æsareæ]. $R[$ egio $] Q[$ ue]. M[aiestatis].

C[onsiliarius $]$.

[na naličju lista (omotu), adresa:]

$\dagger$

Serenissimo Principi ac Domino,

Domino Alberto Archiduci

Austrio, Duci Burgundioe

Comiti Tyrolis etc. Domino,

Domino clementissimo

In Belgium

[pokraj pečata:]

Faustus Verantius Episcopus

Chanadiensis

de portu Ostendano obstruendo

\section{Tekstovi unutar crteža}

[gore, na uzdužnim gredama sa šiljcima:]

trabes

[gore desno:]

istoe catenę debent esse longce

et anchore quatuor uncinorum

sed pictor erravit

[dolje, između prvog i drugog reda poprečnih greda:]

istę catence debent esse distente

non circumducte per trabes

[dolje desno:]

F[austus]. V[erantius]. E[piscopus]. C[hanadiensis]. 6. Sep[tembris] 1603.

Transkripcije je, sa stanovitim razlikama u čitanju, objavio ISTVÁN MONOK (bilj. 4), 151.

\section{Bilješke}

* Ovaj rad nastao je u okviru projekta Instituta za povijest umjetnosti "Graditeljska baština jadranske Hrvatske u ranom novom vijeku i pisani povijesni izvori”.

** Za dragocjenu pomoć u analizi i interpretaciji Vrančićeva projekta za Ostende zahvaljujem kolegi Goranu Nikšiću.

1

Rijksarchief in België/ Archives de l'État en Belgique, Algemeen Rijksarchief/ Archives générales du Royaume, Fond Duitse Staatssecretarie / Secrétairerie d'État Allemande, 413, p. 307-309.
2

LÁSZLÓ MAKKAI, De Taccola à Veranzio. L'ingénieur de la Renaissance en Hongrie, u: Histoire économique du monde méditerranéen 1450-1650. Mélanges en l'honneur de Fernand Braudel, vol. I, Toulouse, 1973., 337-347; 344-345, 347 (bilj. 24).

3

KATALIN S. VARGA, Verancsics Faustus, a humanista tudós, u: Verancsics Faustus. Machinae Novae és más müvei, (ur.) Katalin S. Varga, Budapest, 1985., 361-383; 360, 373. 
4

ISTVÁN MONOK, Verancsics Faustus Ostende kikötőjének megerősítéséröl, u: Verancsics Faustus 1551-1617, (ur.) J. Géczi [Vár Ucca Tizenhét, 1994/3], Veszprém, 1994., 151-152. Podatak o projektu Fausta Vrančića za Ostende bilježe, svatko iz svog očišta, i dvojica autora novijih međunarodnih monografskih publikacija - MARCUS POPPLOW, Neu, nützlich und erfindungsreich: die Idealisierung von Technik in der frühen Neuzeit, Münster - New York - München - Berlin, 1998., 91; te LUC DUERLOO, Dynasty and Piety: Archduke Albert (1598 - 1621) and Habsburg Political Culture in an Age of Religious Wars, Farnham, 2012., 128.

\section{5}

Najrecentniji cjeloviti pregled aktualnog stanja istraživanja Vrančićeva života i opusa donosi IVA KURELAC, Vrančić, Faust, u: Hrvatski biografski leksikon [online], Zagreb, 2018., dostupno na: <http://hbl.lzmk.hr/clanak.aspx?id=12009> (6. rujna 2019.); o tehničkim i tehnološkim aspektima Vrančićeva izumiteljstva vidjeti i: MARIJANA BORIĆ, Vrančićevo djelo Machinae novae u obzoru novovjekovne znanosti, u: Faust Vrančić i njegovo doba - Zbornik radova s medunarodnog znanstvenog skupa (Šibenik Vodice, 22. - 23. rujna 2015.), (ur.) M. Borić - Z. Blažević - B. Marotti, Prvić Luka, 2018., 15-39.

6

EDDY MASSCHALCK, The Port of Ostend Originated in the Sixteenth Century, u: Brussels International Map Collectors' Circle Newsletter, 40 (April 2011.), 18-23; 18-19.

7

CHRISTOPHER DUFFY, Siege Warfare. The Fortress in the Early Modern World, 1494-1660, London, 1979., 85.

8

Općeniti povijesni podatci o opsadi Ostendea u ovom su radu zasnovani na djelima: JOHN LOTHROP MOTLEY, History of the United Netherlands, Vol. 4: From the Death of William the Silent to the Twelve Years' Truce, 1609, London, 1876., i ANNA E. C. SIMONI, The Ostend Story: Early Tales of the Great Siege and the Mediating Role of Henrick van Haestens, 't Goy-Houten, 2003.

9

JOHN LOTHROP MOTLEY (bilj. 8), 58.

10

CHRISTOPHER DUFFY (bilj. 7), 89, navodi da je tijekom opsade u Ostendeu zabilježeno više od 3000 uplovljavanja brodova.

11

ANNA E. C. SIMONI (bilj. 8), passim.

12

U uspravnom pravokutniku odrezanih i blago zaobljenih uglova ovalni štit okružen vegetabilnim ukrasom unutar kojeg su dvije kose grede s po tri ljiljana. Nad štitom, između dvije simetrično povijene vrpce završene srcolikim listovima, biskupska je mitra, a lijevo i desno uz nju su inicijali F i V.

13

Izuzmu li se inicijali, Faustov je grb na pečatu jednak grbu na bakroreznom portretu Antuna Vrančića iz 1570., djelu Martina Kolunića Rote - usp. MILAN PELC, Život i djela šibenskog bakroresca Martina Rote Kolunića, Zagreb, 1997., 32, 189-190. Da stihovi o grbu Vrančićevih na toj Kolunićevoj grafici potječu iz Faustova pera utvrdio je DARKO NOVAKOVIĆ, Sentimentalni odgoj. Antun i Faust Vrančić, Šibenik, 1995., 114. Ondje su, 124-125, ti stihovi objavljeni u latinskom izvorniku i hrvatskom prijevodu Bratislava Lučina. Usp. i MILIVOJ ZENIĆ, U pohvalu od grada Šibenika: pisana riječ od najstarijih vremena do danas, Šibenik, 2002., 136.

14

Usp. FAUSTUS VERANTIUS, Machinae novae Fausti Verantii Siceni cum declaratione Latina, Italica, Hispanica, Gallica et Germanica, Venetiis, s. d., [pretisak], München, 1965., [t.] 27. MODVS PVRGANDI FRVMENTI. Grb na pečatu razlikuje se utoliko što su grede s ljiljanima uleknute a ne ispupčene. $\mathrm{Na}$ grbu Vrančićevih u zabatu edikule na naslovnici iste knjige izostaju inicijali, a umjesto mitre - znamena biskupske časti - nad štitom je maskeron.

15

Navedeno prema: ISTVÁN MONOK (bilj. 4), 151.

16

Navedeno prema: Tide Times for Ostend <https://www.tide-forecast.com/locations/Oostende-Belgium/tides/latest> (6. rujna 2019.).

17

Catena portus Sibenicensis bila je rastezana između dviju tvrđavica nasuprot grada, na ulazu u Kanal sv. Ante / Šibenski kanal (turris magna i turris parva), redovito prikazivanih na panoramskim vedutama grada 16. i 17. stoljeća, usp. JOSIP ĆUZELA, Pomorska utvrda Sv. Nikole na ulazu u kanal Sv. Ante kod Šibenika, u: Prilozi povijesti umjetnosti u Dalmaciji, 33 (1992.), 51-76; 52; JOSIP CUUZELA, Šibenski fortifikacijski sustav, Šibenik, 2005., 64; ilustracije na tablama između str. 48 i 49.

18

ANNA E. C. SIMONI (bilj. 8), 10.

19

ANNA E. C. SIMONI (bilj. 8), 38, 196-197, 204 (bilj. 406).

20

Usp. i LUC DUERLOO (bilj. 4), 128.

21

Opći podatci o Targoneovu životu i djelima u ovom radu potječu iz sljedećih djela: GIOVANNI BAGLIONE, Le vite de' pittori, scultori et architetti. Dal pontificato di Gregorio XIII. del 1572. In fino a' tempi di Papa Urbano Ottavo nel 1642., [1. izd. 1642.], Napoli, 1733., 216-218; CARLO PROMIS, Biografie di ingegneri militari italiani dal secolo XIV alla metà del XVII, Torino, 1874., 799-812; JOHANNES A. F. ORBAAN, Documenti sul baroco in Roma, Roma, 1920., passim; CATHERINE FRUHAN, Targone, Pompeo, u: The [Grove] Dictionary of Art, vol. 30, New York London, 1996., 344-345.

22 LUC DUERLOO (bilj. 4), 148.

23

Od Targoneovih rimskih djela iz tog razdoblja najglasovitiji je pozlaćeni brončani tabernakul u obliku oktogonalnog hrama s kupolom, na oltaru papinske kapele Presvetog Sakramenta u crkvi San Giovanni in Laterano, što ga je po narudžbi Klementa VIII. izradio 1600. godine.

24 GIOVANNI BAGLIONE (bilj. 21), 217.

25 Monografsku studiju o tim povijesnim izvorima napisala je ANNA E. C. SIMONI (bilj. 8).

26

CARLO PROMIS (bilj. 21), 807. 
Rad. Inst. povij. umjet. 43/2019. (181-190)

27

ANNA E. C. SIMONI (bilj. 8), 165.

28

JOHANNES A. F. ORBAAN (bilj. 21), 80.

29

GIOVANNI BAGLIONE (bilj. 21), 217.

30

CARLO PROMIS (bilj. 21), 810-811.

31

Flamanski su autori poput Philipsa Fleminga, pomoćnika zapovjednika opsjedane utvrde, ili Henricka Van Haestensa - usp. ANNA E. C. SIMONI (bilj. 8), 163-172 - neuspjesima Targoneovih naprava pridavali zamjetnu pozornost ne bi li i tako ilustrirali nemoć napadača.

32

Usp. POMPEO GIUSTINIANI, Delle guerre di Fiandra libri 6. Di Pompeo Giustiniano del Consiglio di guerra di S. M. C. ... Posti in luce da Gioseppe Gamurini ... con le figure delle cose più notabili, In Anversa, 1609., 63-64.

33

Targone je spomenut na kraju komentara uz projekt stroja za piljenje kamenih blokova - FAUSTUS VERANTIUS (bilj. 14), 15 (XLIV. SERRA PRO LAPIDIBVS): Hoc idem poterit Aqva Fluviatilis proctare [!], qvod pulcrè nuper in Urbe Targonus ostendit. (»Ovo se isto može izvesti i uz pomoć riječne vode, kako je to nedavno lijepo u Rimu pokazao Targone.«).

\section{4}

MARIA MARGARITA SEGARRA LAGUNES, Il Tevere e Roma: storia di una simbiosi, Roma, 2004., 122-124, 395; IRENE BEVILACQUA, Acque e mulini nella Roma del Seicento, u: Studi di storiografia urbana, 5/1 (2010.), 99-140; 117-126.

\section{5}

Za pouzdanu kronologiju rimskog razdoblja Fausta Vrančića vidjeti: IVICA MARTINOVIĆ, Marko Antun de Dominis vs. Faust Vrančić: od Logike (1608) do Nove logike (1616), u: Prilozi za istraživanje hrvatske filozofske baštine, 42/2 (84) (2016.), 293-330; 305-308.

36

MARIA MARGARITA SEGARRA LAGUNES (bilj. 34), 287-288. 37

FAUSTUS VERANTIUS (bilj. 14), [t.] I. VRBIS ROMA DILVVIVM. O Vrančićevu projektu za regulaciju Tibera raspravlja i MARIA MARGARITA SEGARRA LAGUNES (bilj. 34), 120, 122-124.

38

FAUSTUS VERANTIUS (bilj. 14): (lat.) Machinationes nostrae, $17_{1}-19_{1}$; (tal.) Inventioni nostre, $17_{2}-19_{2}$; (šp.) Invenciones nuestras,
Danko Zelić: Projekt Fausta Vrančića za opsadu Ostendea iz 1603. godine

$19_{3}-20_{3}$; (fr.) Indice des machines de nostre invention, $17_{4}-19_{4}$; (njem.) Unsere Werck oder Machine, $19_{5}-20_{5}$.

39

FAUSTUS VERANTIUS (bilj. 14), 18.

40

O Targoneovu mostu koji se dizao i spuštao prateći promjene vodostaja, postavljenu nizvodno od ostataka Mosta sv. Marije, uništenog bujicom 1598. godine (otad zvanog Ponte Rotto), vidjeti: MARIA MARGARITA SEGARRA LAGUNES, Le attività produttive del Tevere nelle dinamiche di trasformazione urbana: i mulini fluviali, u: Mélanges de l'École française de Rome. Italie et Méditerranée, 118/1 (2006.), 45-52; 49-51; IRENE BEVILACQUA (bilj. 34), 122.

41

JOHANNES A. F. ORBAAN (bilj. 21), 87: (...) questi architetti tutti s'intende non voglino dare, né mostrare li loro dissegni in mano del Targone, perché non vogliono si facci honore con le loro fatiche e però protestano, che prima egli dia fuori il suo dissegno, acciò si veda chi meglio la intenda, perché essi credono, e credo s'ingannino, che detto Targone sia meno intelligente di molti di loro, ma la sua sorte vuole il contrario.

42

GIOVANNI BAGLIONE (bilj. 21), 217-218: (...) gli vene volontà di far due Mole nel Tevere, e per di sopra un ponte di legno co' suoi ordigni, il qual passasse da Ripa grande a Marmorata, e hebbe gratia dal Papa, che il nolo fusse del Targone. Il fece, e lo hauea fortificato di grosse catene, per inalzarlo, e calarlo, come il bisogno del crescimento del Tevere richiedeva; ma venne una mattina all'improviso una crescenza tanto furiosa, che gran roba e alberi grossissimi con grandissima forza condusse sicche dando uno di essi in quella machina, nè avendo tempo di ripararvi, si ruppe, e portò via giù per il Tevere le Mole, e il Ponte, e mandò in fracasso il tutto. (...) Cosi andò in precipizio quell'opera, la quale dicono, che gli fosse di danno per più di 18. mila scudi, e fu la sua rovina. Usp. i IRENE BEVILACQUA (bilj. 34), 122.

43

Nihilominus tamen scio, homines ita esse affectos, ut mayor pars eorum, qvi has meas Machinas viderint, imo ij ipsi qvi antequam eas vidissent, catalogum earum legerant, mirificas esse censuerunt: postea spernent, et pro vulgaribus habebunt. Cur igitur tantum operis, et impensarum, in eis describendis consumpsi? Ut nempe mihimetipsi, et ijs paucis, qvi eas aliqvid esse putaverint, satisfacerem. Priores petens, ut qvas in promptu habent, meliores proferant, vel in posterum comminiscantur, qvo istis reyectis, illis utamur. Izvod u tekstu rada donesen je u prijevodu Vladimira Muljevića, otisnutom $\mathrm{u}$ dodatku hrvatske edicije s pretiskom: FAUSTUS VERANTIUS, Machinae novae Fausti Verantii Siceni cum declaratione Latina, Italica, Hispanica, Gallica et Germanica, Zagreb Šibenik, 1993., s. p.

44

Usp. MARIJANA BORIĆ (bilj. 5), 15-39. 


\section{Summary}

\section{Danko Zelić}

\section{Faust Vrančić's Design for the Siege of Ostend from the Year 1603}

In the early autumn of 1603, Faust Vrančić (Faustus Verantius, Fausto Veranzio) - at the time residing in the imperial capital of Prague, in the service of Emperor Rudolph II - made a design for the obstruction of maritime access to the port of Ostend and sent it to Archduke Albert VII, the commander of a considerable, 100,000-men army that had been unsuccessfully attacking the town of Ostend as of the summer of 1601 . Since then the besieged town had been supplied with troops and victuals by sea and all the assailants' efforts to cut off that vital communication had failed.

Albeit there is no evidence that Vrančić's design had been taken into consideration, let alone that his machine had actually come into being at the battlefield, his project for Ostend, preserved in the Royal Archives of Belgium in Brussels, is in several respects an important testimony of his activity as inventor. Firstly, besides those presented in his book Machinae novae (Venice, 1615), it remains the only surviving drawing of any of his devices. Secondly, the design for Ostend is not a 'conceptual' invention, but a custom-made solution for a specific purpose and, thirdly, it was apparently developed on his own initiative.

Although designed to serve the besieging party, Vrančićs device for Ostend is in fact a defensive war machine - a combination of two types of barriers for incoming enemy ships. The first one (in the upper part of the drawing) features longitudinal pointed wooden beams disposed in two rows with the aim of damaging and/or breaching ships' hulls. Reinforced with iron, pointed tops of beams are tied to anchors, while their lower parts are fixed into the bottom of the channel/waterway. The posterior part of the device (in the lower part of the drawing) consists of three transversely disposed rows of shorter floating beams. Connected to each other with chains and anchored to the bottom, they were intended to block further movement of vessels.

In addition to that, the drawing also contains evidence of the evolution of the initial design or, more precisely, two phases of its elaboration. Adjustments regarding the length of chains and the shape of anchors are evident in annotations added by Vrančić himself. Unless his claim that it was the draughtsman (literally: pictor) who had failed is actually true, one can speculate that the modifications are due to the fact that the inventor subsequently gathered more precise information on the particular nature of the site. Thus the sandy sea bottom would be the reason why he opted for four-fluke instead of double-fluke anchors, whereas lengthier anchor chains were more appropriate with regard to considerable tidal range on that area of the North Sea coast.

Vrančić's design is here being considered with regard to the works of his contemporary Pompeo Targone, the Roman engineer employed by the attacking party at Ostend. As a matter of fact, according to the earliest accounts of the siege, particularly the Dutch ones, Targone became notorious as inventor of some spectacular, yet completely unsuccessful war machines. Nevertheless, in spite of being deemed a typical drawing board engineer, i.e. one with no war experience, Targone had also designed some less-known machines in Ostend that had proven to be considerably efficient. At any rate, his fame in Rome was certainly not diminished by the bad reputation acquired in Flanders.

From 1605 onwards, both Faust Vrančić and Pompeo Targone lived in Rome and both of them endeavoured to propose the solution to prevent flooding of the Tiber River, a critical task that numerous engineers of the time were engaged with. While Targone, appointed by Pope Paul V as the chief engineer sopra le acque in 1607, was a professional in charge of the watercourses of Rome, it is less known that Vrančić had been working on the same hydraulic problem himself. Moreover, he decided that this project - termed Urbis Romae diluvium - would indeed be the first among those presented in his book of machines.

Attention should also be drawn to the fact that - although the commentaries accompanying his Machinae novae occasionally mention other contemporary machines and inventors - the only engineer Vrančić explicitly refers to (when explaining his own invention of the stone saw) is indeed Targone. However, despite certain further coincidences, in the concluding part of the paper it is argued that the evidence concerning inventors and inventorship in the early seventeenth century hardly suffices for the discussion of topics such as originality, innovativeness, or authorship. Considering the fact that they are tied to concepts developed at a later time, the very use of these terms would be anachronistic.

Keywords: Faust Vrančić, siege of Ostend, war machines, seventeenth century, military engineering, inventions, Pompeo Targone 


\section{Izvori ilustracija i autori fotografija / Sources of illustrations and photo Credits}

\begin{abstract}
Višnja Bralić
The Cult of Saint Euphemia, the Patron Saint of Rovinj, and the Venetian Politics of Co-creating Local Identities in Istrian Communities in the $15^{\text {th }}$ Century / Kult sv. Eufemije, zaštitnice Rovinja $i$ venecijanska politika sukreiranja lokalnih identiteta u istarskim zajednicama 15. stoljeća
\end{abstract}

1: (c) Museo Correr, Venezia (Giuseppe Rosaccio, Viaggio da Venezia a Costantinopoli, per mare e per Terra, \& insieme quello di Terra Santa, Venetia: Giacomo Franco, 1598, fol. 7v)

2-10: Ljubo Gamulin

\section{Anna Boreczky}

Historiography and Propaganda in the Royal Court of King Matthias: Hungarian Book Culture at the End of the Middle Ages and Beyond / Historiografija i propaganda na dvoru kralja Matije Korvina. Mađarska kultura knjige krajem srednjega vijeka i dalje

1-11, 14, 16-18: @ National Széchényi Library, Budapest (Országos Széchényi Könyvtár)

12, 13: ( ) Heidelberg University Library (Universitätsbibliothek Heidelberg)

15: From Wikimedia Commons, the free media repository

\section{Ivan Gerát}

Saint George Between Media and Functions / Sv. Juraj izmedu medija i funkija

1: Image courtesy National Gallery of Art, Washington DC

2: https://www.metmuseum.org/art/collection/, Public Domain

3: https://www.metmuseum.org/art/collection/, Public Domain

4, 5: Ivan Gerát

6: Archive of the Institute of Art History of the Slovak Academy of Sciences

\section{Ivan Ferenčak}

The Illustrations in the Glagolitic Books Printed by Bishop Šimun Kožičić Benja in Rijeka (1530-1531) / Ilustracije u glagoljskim knjigama biskupa Šimuna Kožičića Benje tiskanim u Rijeci (1530.-1531.)

1: Tamara Runjak, Rijetkosti u Knjižnici Hrvatske akademije znanosti i umjetnosti: katalog inkunabula i knjiga 16. stoljeća, Zagreb, 2011.

2, 7-10: Zagreb, Knjižnica Hrvatske akademije znanosti i umjetnosti, R-600, snimio Ivan Ferenčak 2019.

3: Ivan Ferenčak, 2019.

4: Biblioteca nazionale Marciana, Venezia, BM - Rari Ven. 579 (su concessione del Ministero per i Beni e le Attività Culturali - Biblioteca Nazionale Marciana. Divieto di riproduzione).

5: Biblioteca nazionale centrale di Firenze, Firenze, MAGL.2.1.109 (su concessione del Ministero dei beni e delle attività culturali. Biblioteca Nazionale Centrale di Firenze. Divieto di riproduzione)
6: Bibliothèque nationale de France, Paris, département Musique, RES-1527.

11: Nacionalna i sveučilišna knjižnica, Zagreb, RIIA- $8^{\circ}-8$.

12: Nacionalna i sveučilišna knjižnica, Zagreb, RIIA-16º-5.

\section{Milan Pelc}

Panegyric Emblem Books, Jesuits and the Habsburg Emperors: Some Examples Related to $17^{\text {th }}$-Century Croatia / Panegirički amblemi $i$ habsburški carevi - primjeri iz 17. stoljeća povezani s hrvatskom kulturnom sredinom

1: ๔ Hrvatski povijesni muzej, Zagreb / Croatian History Museum 2: ( University Library, Budapest / Egyetemi Könyvtár, Kézirattár 3-20: ๑ Austrian National Library, Vienna / Österreichische Nationalbibliothek

\section{Polona Vidmar}

Coesari in mis omni hora fidelis servivi: The Portraits of Sigismund Herberstein and Walter Leslie in Diplomatic Robes / Cæsari in mis omni hora fidelis servivi: Portreti Žigmunda Herbersteina $i$ Waltera Leslieja u diplomatskim odorama

1-2, 4, 6: Knjižnica Ivana Potrča Ptuj / Ivan Potrč Library Ptuj 3: Hollstein's German Engravings, Etchings and Woodcuts 1400-1700, vol. XIII A, 1984

5, 10, 13: Google Books

7-9, 11-12: Polona Vidmar

\section{Nóra G. Etényi}

Broadsheets with Engravings in a Manuscript Chronicle from Ulm: Visual Representations of the Hungarian Kingdom on German Political Leaflets during the War of Reconquest (1683-1699) / Grafički plakati u rukopisnoj kronici iz Ulma: Vizualna reprezentacija Ugarskog Kraljevstva na njemačkim političkim letcima tijekom Velikog turskog rata (1683.-1699.)

1, 4: (C) Austrian National Library Portrait Collection, Vienna / Österreichische Nationalbibliothek Porträtsammlung

2, 3, 6: @ Hungarian National Museum, Budapest / Magyar Nemzeti Múzeum

5, 7: @ National Széchényi Library, Budapest, Apponyi Sammlung / Országos Széchényi Könyvtár, Apponyi Metszet

\section{Werner Telesko}

Graphic prints of the Josephine period (1765/1790) and the propaganda of 'Religious Tolerance' / Grafički listovi Jozefinskog razdoblja (1765./1790.) i propaganda "Vjerske tolerancije"

1: ( ) Austrian National Library, Vienna

2: () Austrian National Library, Vienna

3: ㄷ Vienna Museum 
4: (C) Vienna Museum

5: (C) Vienna Museum

6: C Vienna Museum

\section{Martina Frank}

Representing the Republic in Seventeenth-Century Venice / Predstavljanje Republike u Veneciji 17. stoljeća

1, 3, 4, 5, 12: @ Austrian National Library, Vienna / Österreichische Nationalbibliothek

2, 15: Martina Frank

6: () University Library of Padua / Biblioteca universitaria di Padova

7: @ McNay Art Museum

8: Cat Bauer (https://venetiancat.blogspot.com/2016/11/thanksgiving-in-venice-celebrates-black.html)

9, 10: https://www.lamoneta.it/topic/157941-medaglia-nicol\% C3\%B2-contarini/

11: ๑ José Luiz Bernardes Ribeiro / CC BY-SA 4.0

13: Internet culturale

14: () Marciana National Library / Biblioteca Nazionale Marciana, Venezia

16: ( ) Museo Civico del Castello di San Giusto, Trieste

\section{Bálint Ugry - Maja Žvorc}

The Čakovec Stone Bust Collection: New Identifications, Possible Dating and the Identity of its Commissioner / Zbirka kamenih bisti u Čakovcu: Nove identifikacije, moguće datacije i naručitelj

1, 4, 6, 8, 10: Jovan Kliska

2: ๑ Austrian National Library (Österreichische Nationalbibliothek), Vienna

13, 15: ( ) Museum of Međimurje (Muzej Međimurja), Čakovec

3, 5, 7, 9, 11, 14, 16: Corpus Juris Hungarici, Tyrnaviae, 1751.

12: ( National Széchényi Library (Országos Széchényi Könyvtár), Budapest

17, 18: @ National Archives of Hungary (Magyar Nemzeti Levéltár), Budapest

19: Bálint Ugry

\section{Damir Tulić}

Glory Crowned in Marble: Self-promotion of Individuals and Families in Seventeenth- and Eighteenth-Century Monuments in Istria and Dalmatia / Slava okrunjena mramorom: Samopromocija osoba $i$ obitelji na spomenicima 17. i 18. stoljeća u Istri i Dalmaciji

1, 2, 3, 4, 5, 6, 7, 8, 9, 10, 11, 12, 13, 15, 16, 17: Damir Tulić

14: Samo Štefanac

\section{Jasminka Najcer Sabljak}

Portraits of Habsburg Rulers in the Aristocratic Collections of Eastern Croatia / Portreti vladara obitelji Habsburg u plemićkim zbirkama istočne Hrvatske

\author{
1, 2: ( $)$ Galerija Matice srpske, Novi Sad \\ 3: Francisca Clary-Aldringen \\ 4: Davor Šarić
}

\section{Danko Zelić}

Projekt Fausta Vrančića za opsadu Ostendea iz 1603. godine / Faust Vrančićs Design for the Siege of Ostend from the Year 1603

1: Matthias Dögen, Architectura militaris moderna (...), Amstelodami, 1647., 354-355.
2-4: ( ) Rijksarchief in België / Archives de l'État en Belgique, Algemeen Rijksarchief / Archives générales du Royaume, Fond Duitse Staatssecretarie / Secrétairerie d'État Allemande, 413, p. 309

5: Pompeo Giustiniano, Delle guerre di Fiandra libri 6. Di Pompeo Giustiniano del Consiglio di guerra di S. M. C. (...) Posti in luce da Gioseppe Gamurini (...) con le figure delle cose più notabili, In Anversa, 1609., 84-85

\section{Radoslav Tomić}

Generalni providur Leonardo Foscolo i umjetnost u Dalmaciji / Provveditore generale Leonardo Foscolo and Art in Dalmatia

1-30: Fotografije iz arhive autora

4: Presnimak iz: Alfons Pavich pl. Pfauenthal, Prinosi povijesti Poljica, Sarajevo, 1903., 79.

\section{Petar Puhmajer}

Dvorac Cernik - kontinuitet i mijene predturskog nasljeđa u barokno doba / The Cernik Castle - Continuity and Change in the Pre-Ottoman Heritage during the Baroque Era

1, 2, 9: Paolo Mofardin, Fototeka IPU

3 a, b; 6 a , b c c, d: arhitektonski snimak Sanja Štok i Barbara Kulmer, grafička obrada Marin Čalušić

4, 7, 10, 11: Petar Puhmajer

5: ๑ Generallandesarchiv, Karlsruhe

\section{Bojan Goja}

Kuća Cattinelli 1772. godine: prilog poznavanju stambene arhitekture u Zadru u 18. stoljeću /

The Cattinelli House in 1772: A Contribution to Our Knowledge of Housing Architecture in $18^{\text {th }}$-Century Zadar

1, 2: Bojan Goja

3, 4: Branko Maroević, dipl. ing. arh., izrada nacrta

\section{Iva Pasini Tržec}

Slike starih majstora iz zbirke Ervina i Branke Weiss u Strossmayerovoj galeriji u Zagrebu / Paintings of Old Masters from the Collection of Ervin and Branka Weiss in the Strossmayer Gallery in Zagreb

1, 3, 6: Arhiv Strossmayerove galerije HAZU, dokumentacija Weiss 2: MAK - Museum of Applied Arts (Museum für angewandte Kunst), Vienna

4: RKD - Netherlands Institute for Art History (Rijksbureau voor Kunsthistorische Documentatie), Den Haag

5: Palais Liechtenstein, Vienna

6: ( ) Strossmayerova galerija starih majstora HAZU

7: BDA - Bundesdenkmalamt Archiv (Federal Monuments Authority Austria Archive), Vienna

\section{Irena Kraševac}

Prva tri djela u fundusu Moderne galerije Društva umjetnosti / The First Three Artworks in the Holdings of the Modern Gallery of the Art Society in Zagreb

1, 4: Goran Vranić, Moderna galerija, Zagreb

2: Paolo Mofardin, Institut za povijest umjetnosti, Zagreb

3: digitalna presnimka iz kataloga izložbe: Ivan Meštrović. Skulpturen, Nationalgalerie, Staatliche Museen Preußischer Kulturbesitz, Berlin, 1987. (Nenad Gattin?)

5: Arhiv Galerije grada Praga / Archive of Prague City Gallery 